\title{
The Role of Janus Kinase 2 (JAK2) in the Pathologenesis of Myeloproliferative Disorders
}

\author{
Mamdooh A. Gari, $\mathrm{PhD}$ \\ Department of Medical Laboratory Technology, Faculty of Applied Medical \\ Sciences, Center of Excellence in Genomic Medicine Research, \\ King Abdulaziz University, Jeddah, Saudi Arabia \\ m_gari@hotmail.com
}

\begin{abstract}
The myeloproliferative disorders, polycythemia vera, essential thombocythemia, and primary myelofibrosis are clonal disorders of multipotent hematopoietic progenitors. The genetic cause of these diseases was not known until 2005, when several independent groups demonstrated that most patients with PV, ET and PMF acquired a single point mutation in the cytoplasmic tyrosine kinase, such as JAK2 (JAK2 V617F). These discoveries have changed the landscape for diagnosis and classification of PV, ET and PMF, and have shown the ability of genomic technologies to identify new molecular targets in human malignancies with pathogenetic, diagnostic and therapeutic significance.
\end{abstract}

Keywords: Leukemia, Tyrosine kinase, Myeloproliferative disorders, JAK 2 mutations

\section{Introduction}

Myeloproliferative disorders (MPD) are clonal disorders of hematopoietic progenitors, and include the classical MPD chronic myeloid leukemia (CML), polycythemia vera (PV), essential thrombocythemia (ET) and primary myelofibrosis (PMF), as well as chronic eosinophilic leukemia (CEL), chronic myelomonocytic leukemia (CMML), and systemic mastocytosis (SM) and others. The different myeloproliferative disorders (MPD) can be classified by the predominant

\footnotetext{
Correspondence \& reprint request to:

Dr. Mamdooh A. Gari

P.O. Box 80216, Jeddah 21589, Kingdom of Saudi Arabia

Accepted for publication: 15 February 2009. Received: 10 November 2008.
} 
terminally differentiated myeloid cell involved in the disorder, and for each terminally differentiated myeloid cell there is a clinically distinct MPD. Different approaches have been used to identify the activating alleles that cause these disorders, and in all cases these alleles result in constitutive tyrosine kinase signaling. HSC, hematopoietic stem cell; JAK2, Janus kinase 2; MPL, thrombopoietin receptor; PDGFR, platelet derived growth factor receptor (Fig. 1). Although, each of the MPD is recognized as a distinct clinicopathological entity, these disorders share cardinal features that distinguish the MPD from other myeloid malignancies $^{[1]}$, namely myelodysplastic syndromes (MDS) and acute myeloid leukemia (AML). In the past two decades, mutant alleles have been identified in CML, CMML, CEL and $\mathrm{SM}^{[2-5]}$. In each case the causative mutation results in constitutive activation of tyrosine kinase

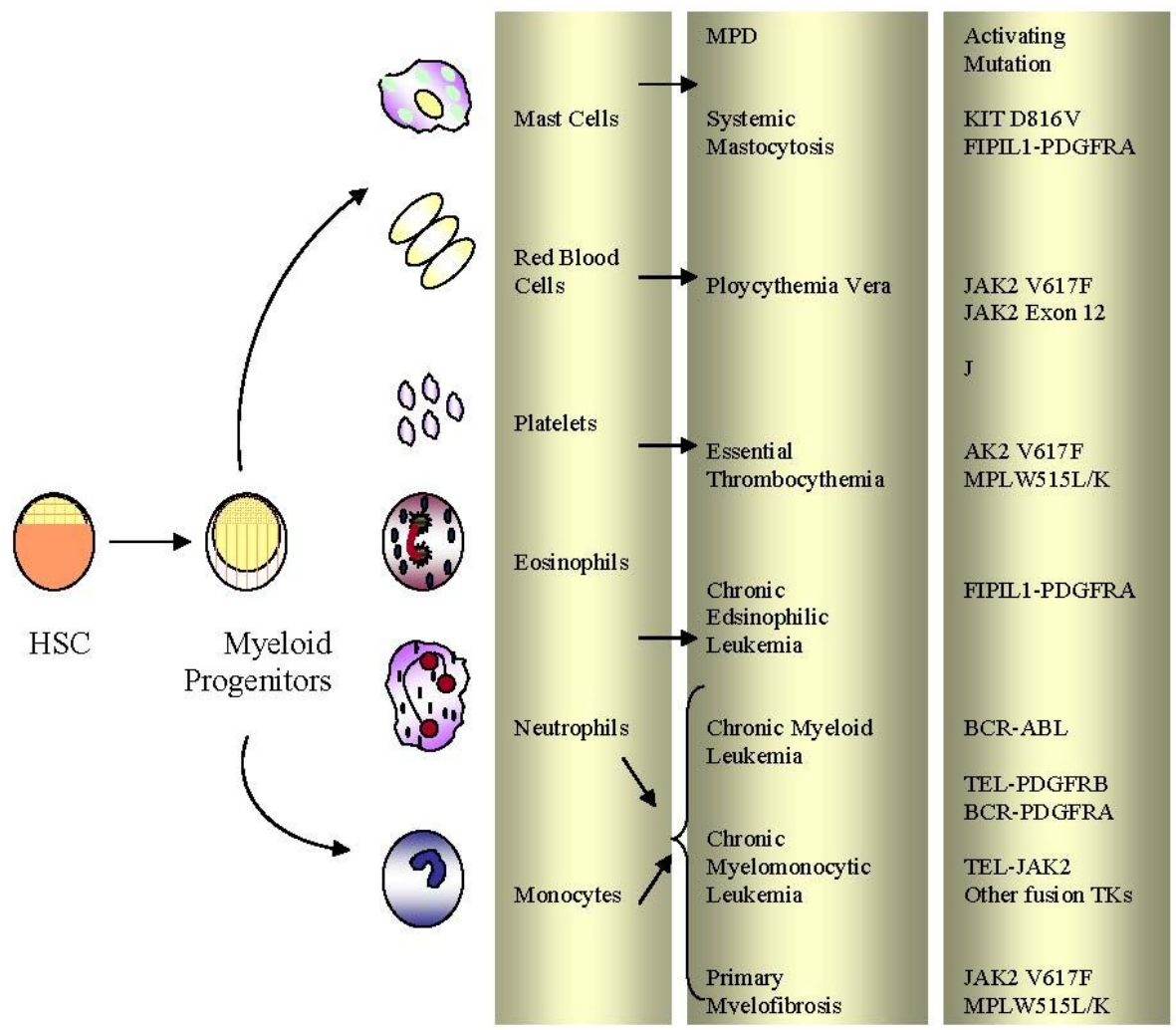

Fig.. 1. MPD classification and molecular pathogenesis. 
signaling. Perhaps, the most important from a clinical perspective, specific inhibition of these activated kinases results in dramatic clinical efficacy in the treatment of MPD ${ }^{[4-7]}$. Collectively, these data indicate that tyrosine kinase activation is a common pathogenetic mechanism in MPD, moreover these mutated kinases serve as validated targets for the design of molecularly targeted therapies. Although, these discoveries provided an important insight into the pathogenesis and treatment of certain MPD, the genetic causes of the most common MPD remained unknown; until the identification of mutations that activate Janus kinase 2 (JAK2) signaling in most patients with PV, ET or $\mathrm{PMF}^{[8-11]}$. In this mini review report, the discussion will include our understanding of the genetic basis of these disorders, in particular relating to the role of JAK2 activation in the pathogenesis of PV, ET and PMF.

\section{JAK2 V617F Mutations in PV, ET and PMF}

In 2005, several independent groups used different experimental approaches to identify a recurrent mutation in the $J A K 2$ tyrosine kinase in most patients with PV, ET or $\mathrm{PMF}^{[8-11]}$. JAK2 is a member of the Janus family of cytoplasmic non-receptor tyrosine kinases, which also includes JAK1, JAK3 and TYK2. The mutation is a G-T substitution at nucleotide 1849, which results in substitution of V-F at amino acid position 617 of JAK2 (JAK2 V617F). The mutation is present in hematopoietic cells, but not germline DNA in patients with $\mathrm{MPD}^{[8-11]}$, demonstrating that $J A K 2 V 617 F$ is a somatic mutation that is acquired in the hematopoietic compartment. In addition, the JAK2 $V 617 F$ allele can occasionally be present in different hematopoietic compartments ${ }^{[12,13]}$, including $\mathrm{B}$ and $\mathrm{T}$ lymphoid cells. These findings suggest that the mutation might occur in the pluripotent hematopoietic stem cell; indeed, the $J A K 2 V 617 F$ allele has recently been identified in the hematopoietic stem cell (HSC) compartment in patients with $\mathrm{PV}^{[14]}$. These data are in agreement with the hypothesis that the self-renewing properties of HSCs are necessary for the MPD phenotype, and that activated tyrosine kinases can transform HSCs, but not myeloid progenitors that lack the capacity for self-renewal ${ }^{[15]}$.

In the initial reports of the JAK2 $V 617 F$ allele in PV, ET and PMF, it was noted that, although, most patients with MPD are heterozygous for $J A K 2 V 617 F$, a subset of patients, most commonly with 
$\mathrm{PV}$, are homozygous for the $J A K 2 V 617 F$ allele ${ }^{[8-11]}$. The mechanism of homozygosity for $J A K 2 V 617 F$ is not loss of the wild-type allele, as is observed for classical tumor-suppressor genes, but instead results from mitotic recombination and duplication of the mutant allele $\mathrm{MPD}^{[8-11]}$, known as acquired uniparental disomy (UPD). UPD involving chromosomal locus 9p24, including $J A K 2$, had previously been noted in $\mathrm{PV}^{[16]}$, and Kralovics et al. identified the $J A K 2 \quad V 617 F$ allele through analysis of the minimal region of UPD in $\mathrm{PV}^{[11]}$. Homozygous $J A K 2$ $V 617 F$ mutant erythroid colonies can be grown from almost all patients with $\mathrm{PV}^{[17]}$; suggesting that UPD at the JAK2 locus resulting in $J A K 2$ $V 617 F$ homozygosity is an early event in the pathogenesis of PV. By contrast, homozygous JAK2 $V 617 F$ mutations are rarely observed in $\mathrm{ET}^{[8]}$, and hematopoietic colonies have grown from ET patients are most commonly wild type or heterozygous with respect to $J A K 2$. These data suggested that there are important genetic differences between PV and ET, and that duplication of $J A K 2 V 617 F$ is the most important to the pathogenesis of PV.

After the discovery of the $J A K 2 V 617 F$ allele, sensitive, allelespecific assays have been used to assess the frequency of $J A K 2 V 617 F$ mutations in different malignancies ${ }^{[10,17-19]}$ (Table 1). Although, JAK2 $V 617 F$ mutations are most common in PV, ET and PMF, they occur less commonly in other myeloid diseases; including CMML, MDS and $\mathrm{AML}^{[19-22]}$, whereas acquisition of JAK2 $V 617 F$ does not occur in lymphoid malignancies or in solid tumors. The predilection of JAK2 $V 617 F$ mutations for myeloid malignancies is surprising, given that there is significant evidence that activation of Jak-Stat (signal transducer and activator of transcription) signaling occurs in a wide spectrum of human malignancies ${ }^{[23]}$. Existing genetic data suggested that there are desperate mechanisms for activation of Jak-Stat signaling in different malignancies; including JAK2 V617F mutations in myeloid malignancies, $J A K 3$ mutations in megakaryoblastic leukemia ${ }^{[24]}$. JAK2 amplification and suppressor of cytokine signaling 1 (SOCS1) mutations in Hodgkin disease and mediastinal large B-cell lymphoma ${ }^{[25-28]}$, and promoter hypermethylation of SOCS1 in multiple myeloma ${ }^{[29]}$. As highresolution genomic strategies improve, our understanding of the cancer genome novel genomic events that result in activation of Jak-Stat signaling are likely to be identified in hematopoietic and nonhematopoietic neoplasms. 
Table 1. Frequency of the $J A K 2 V 617 F$ allele in myeloid disorders.

\begin{tabular}{l|c}
\hline \multicolumn{1}{c}{ Disease } & Frequency \\
\hline Polycythaemia Vera & $81-99 \%$ \\
\hline Essential Thombocytosis & $41-72 \%$ \\
\hline Primary Myelofibrosis & $39-57 \%$ \\
\hline Chronic Myelomonocytic Leukemia & $3-9 \%$ \\
\hline Myelodysplasia & $3-5 \%$ \\
\hline Acute Myeloid Leukemia & $<5 \%$ \\
\hline $\begin{array}{l}\text { Most common in patients with refractory anemia with ringed sideroblasts and thombocytosis. A clinically distinct subtype of } \\
\text { myelodysplastic syndromes. }{ }^{*} \text { Most common in patients with a previous history of polycythemia vera, essential } \\
\text { thrombocytopenia and primary myelofibrosis. }\end{array}$
\end{tabular}

\section{$J A K 2$ V617F and Signal Transduction}

The Jak Kinases normally function through their association with cytokine receptors that lack intrinsic kinase activity. Ligand binding to the appropriate cytokine receptor results in Jak kinase phosphorylation and activation, cytokine receptor phosphorylation, recruitment and phosphorylation of Stat proteins; and the activation of downstream signaling proteins. The specificity of different cytokine receptors for one or more different Jak kinases accounts in part for their differential effects on signal transduction. Genetic deletion of JAK2 results in embryonic lethality owing to a lack of definitive erythropoiesis, and JAK2-deficient hematopoietic progenitors do not respond to erythropoietin (EPO) stimulation; these data demonstrate JAK2 is the sole Jak kinase responsible for EPO receptor (EPOR) signaling ${ }^{[30]}$.

The Jak kinases have seven homologous domains (JH1-7), which include the catalytic kinase domain ( $\mathrm{JH} 1)$ and a catalytically inactive pseudokinase domain (JH2). The JAK2 V617F point mutation results in a single amino acid substitution within the $\mathrm{JH} 2$ domain of JAK2. It has been suggested that the $\mathrm{JH} 2$ domain serves as an auto inhibitory function similar to the juxtamembrane domain of receptor tyrosine kinases ${ }^{[31]}$, and that valine 617 has an important role in mediating JAK2 kinase autoinhibition $^{[32]}$. The valine-to-phenylalanine substitution at codon 617 might abrogate autoinhibition and result in constitutive kinase activity ${ }^{[33]}$, although, structural insight is needed to determine if this is the case. The $J A K 2$ V617F protein has constitutive kinase activity ${ }^{[34]}$, and when expressed in vitro JAK2 $V 617 F$, but not wild-type JAK2, is constitutively phosphorylated $^{[8]}$, which is consistent with the notion that $J A K 2 V 617 F$ is a gain-of-function mutation with respect to JAK2 kinase activity. 
Expression of $J A K 2 \mathrm{~V} 617 \mathrm{~F}$ confers cytokine hypersensitivity and cytokine-independent growth to hematopoietic cells, which are characteristic features of hematopoietic colonies grown from patients with $\mathrm{PV}^{[35]}$. JAK2V617F-mediated transformation to cytokineindependent growth is most efficient in hematopoietic cells that coexpress the EPOR, the thrombopoietin receptor (MPL), or the granulocyte colony-stimulating factor receptor $(\mathrm{GCSFR})^{[36]}$. Unlike most cytokine receptors, EPOR, MPL and GCSFR are homodimeric type I cytokine receptors that are expressed on cells of the erythroid, megakaryocytic and granulocytic lineages, respectively. Although, these data do not exclude the possibility that $J A K 2$ V617F interacts with nonhomodimeric hematopoietic cytokine receptors; unlike other activated tyrosine kinases that have been identified in human malignancies, JAK2V617F-mediated hematopoietic cell transformation requires interaction with a cytokine receptor scaffold. In addition, the predilection of the JAK2 $V 617 F$ allele for proliferative syndromes involving the erythroid, megakaryocytic and granulocytic lineages, might in part be explained by differential cytokine receptor expression during hematopoietic differentiation.

In vitro studies, demonstrate that the expression of $J A K 2 \mathrm{~V} 617 \mathrm{~F}$ activates multiple downstream signaling pathways ${ }^{[8,36]}$, including the Stat family of transcription factors, the mitogen activated protein kinase (MAPK) signaling pathway, and the phosphotidylinositol 3-kinase (PI3K)-Akt signaling pathway. Cytokine ligands normally bind cytokine receptors, which results in Janus kinase 2 (JAK2) phosphorylation, recruitment of signal transducer; an activator of transcription (Stat) signaling proteins and phosphorylation, An activation of downstream signaling pathways, including Stat transcription factors, mitogen activated protein kinase (MAPK) signaling proteins, and the phosphotidylinositol 3-kinase (PI3K)-Akt pathway (Fig. 2). Most activated tyrosine kinases that have been identified in human malignancies activate these same signaling cascades. The role and requirement of the Stat, MAPK and PI3K-Akt signaling pathways in JAK2 V617F-mediated transformation of hematopoietic cells has not been fully elucidated. However, several lines of evidence suggest that activation of the Stat family of transcription factors is important in JAK2 V617F-mediated transformation. First, expression of either constitutively 


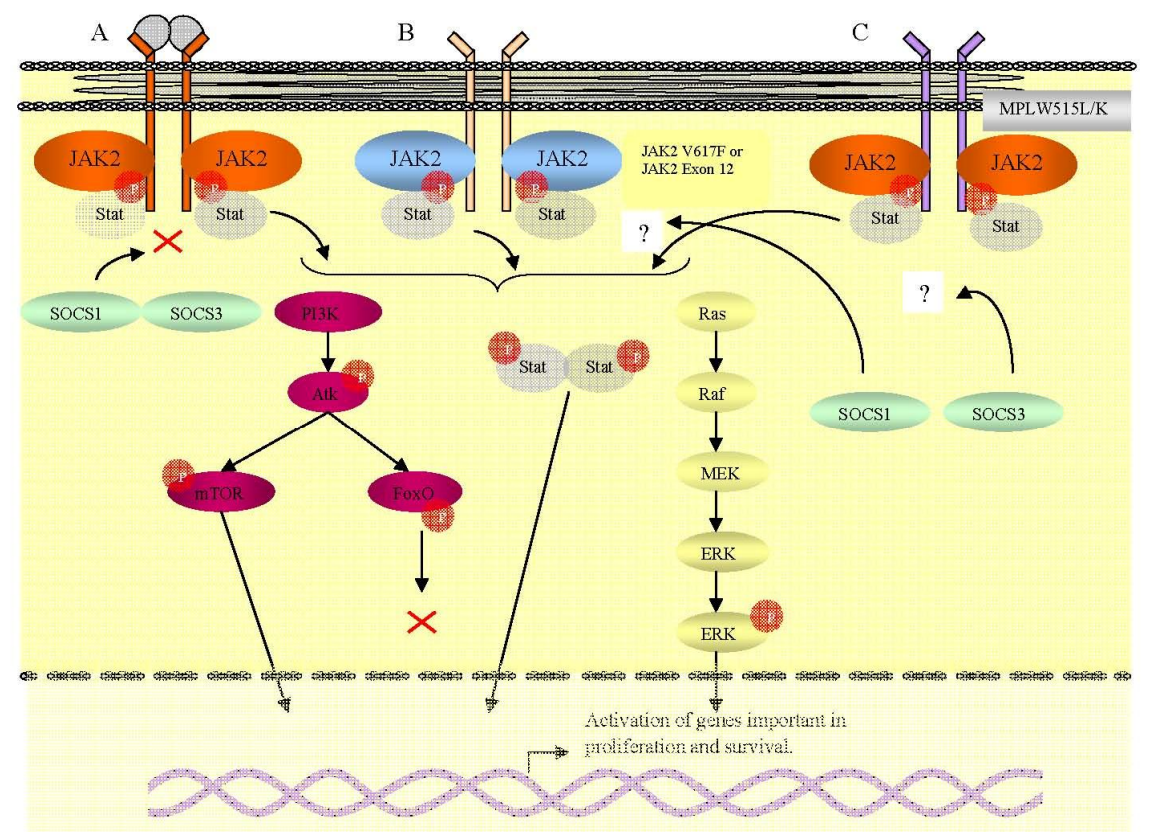

Fig. 2. The mechanism of activation of JAK2 kinase activity by mutations in the JAK2 signaling pathway. (A) Cytokine ligands normally bind cytokine receptors. (B) Mutant JAK2 (V617F and JAK2 exon 12 mutant kinases) lead to ligand-independent activation of downstream signaling pathways. (C) MPLW515L/K mutant thrombopoietin receptors are able to phosphorylate wild-type JAK2 in the absence of thrombopoietin.

active STAT5 or its anti-apoptotic target gene BCL- $\mathrm{X}_{\mathrm{L}}$ in human hematopoietic progenitors results in EPO-independent colony formation $^{[37]}$; a hallmark of human PV. Moreover, STAT3 activation and BCL-X $\mathrm{L}_{\mathrm{L}}$ over expression are observed in most PV patient samples ${ }^{[38,39]}$. These data imply that Stat pathway activation is important in JAK2 V617F-mediated transformation, but do not indicate whether Stat pathway activation is necessary and/or sufficient for JAK2 V617Fmediated transformation. Murine bone marrow transplantation (BMT) assays using Stat5a; Stat5b-deficient mice have been used to show that STAT5 is required for hematopoietic transformation by the constitutively active TEL-JAK2 fusion tyrosine kinase ${ }^{[40]}$, and future experiments will ultimately determine whether the same is true for $J A K 2$ V617F. In 
addition, the activation of signaling by the JAK2 V617F kinase might in part be due to escape from negative-feedback mechanisms important in attenuating JAK2 signal. JAK activity is negatively regulated by the Socs family of proteins, which normally bind to the Jak kinases and result in their degradation. In particular, SOCS1 and SOCS3 have been shown to bind to JAK2 and inhibit JAK2 catalytic activity ${ }^{[41,42]}$. Over expression of SOCS1 results in abrogation of in vitro and in vivo transformation by TEL-JAK2 ${ }^{[43]}$. Although, expression of SOCS1 results in JAK2 and $J A K 2 V 617 F$ degradation and inhibition of kinase activity, the expression of SOCS3 paradoxically results in increased JAK2 V617F protein stability, increased SOCS3 phosphorylation and increased JAK2 $V 617 F$ phosphorylation ${ }^{[4]}$. These data demonstrate that regulation of JAK2 kinase activity by SOCS3 is altered in the context of the V617F substitution, and suggest the possibility that therapeutic inhibition of SOCS3 might selectively attenuate $J A K 2 V 617 F$, but not wild-type JAK2 signaling.

In vivo data from murine BMT experiments have provided important insights into the role of JAK2 activation in the pathogenesis of MPD. James et al. noted that the expression of $J A K 2 V 617 F$, but not in wild-type JAK2, in a murine BMT assay results in significant erythrocytosis in recipient mice 28 days after transplantation ${ }^{[8,9]}$. Subsequent studies by several groups have confirmed and extended these findings ${ }^{[45-48]}$ (Table 2). Several important observations can be made based on the data from these studies. First, although, expression of most activated tyrosine kinases in a murine BMT model results in a neutrophilic MPD most similar to human $\mathrm{CML}^{[47-50]}$, the predominant phenotype that results from in vivo JAK2 V617F expression is erythrocytosis. By contrast, leukocytosis is observed in the $\mathrm{Balb} / \mathrm{C}$, but not the $\mathrm{C} 57 \mathrm{~B} 1 / 6$ genetic background ${ }^{[45,47]}$, suggesting that there are genetic modifiers which influence the phenotype of JAK2 V617Fpositive hematopoietic progenitors. In addition, although thrombocytosis is commonly observed in $\mathrm{PV}$ and $\mathrm{ET}$, expression of JAK2 V617F it does not induce thrombocytosis in recipient in mice. These data indicate that expression of JAK2 $V 617 F$ by itself might result in human PV, but that additional genetic events are necessary for the development of ET and/or PMF. 
Table 2. Murine models of MPD.

\begin{tabular}{|c|c|c|c|c|c|c|}
\hline 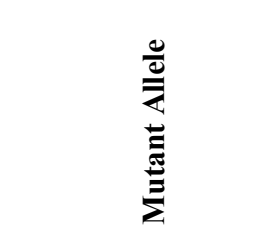 & 㫄 & $\vec{a}$ & 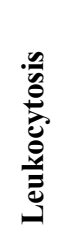 & 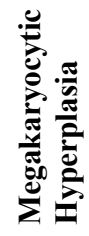 & 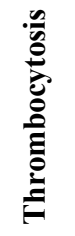 & 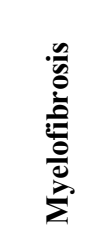 \\
\hline$J A K 2$ V6 $617 F^{45,47,48]}$ & $\mathrm{Balb} / \mathrm{C}$ & Yes & Yes & Yes & No & Yes \\
\hline$J A K 2 V 617 F^{[45-47]}$ & $\mathrm{C} 57 \mathrm{Bl} / 6$ & Yes & No & Yes & $\mathrm{No}^{*}$ & Modest \\
\hline$J A K 2$ exon $12^{[53]}$ & $\mathrm{Balb} / \mathrm{C}$ & Yes & Yes & Yes & No & Yes \\
\hline MPLW515L $L^{[55]}$ & $\mathrm{Balb} / \mathrm{C}$ & No & Yes & Yes & Yes & Yes \\
\hline
\end{tabular}

JAK2 V617F-Negative PV, ET and PMF

Although, JAK2 V617F mutations can be identified in many patients with PV, ET and PMF, a significant proportion of patients with ET, PMF and a small number of patients with PV are JAK2 V617F negative. Clonal hematopoiesis is observed in patients with $J A K 2 \mathrm{V6} 17 \mathrm{~F}$ negative $\mathrm{MPD}^{[30]}$, suggesting alternate alleles account for myeloproliferation in this setting. Moreover, serial assessment of JAK2 $V 617 F$ status in $J A K 2 V 617 F$-negative MPD did not observe conversion to $J A K 2 V 617 F$-positive $\mathrm{MPD}^{[51]}$, indicating $J A K 2 V 617 F$-negative MPD are pathogenetically distinct from $J A K 2 V 617 F$-positive MPD.

\section{JAK2 Exon 12 Mutations in V617F-Negative PV}

Although, most patients with $\mathrm{PV}$ are $J A K 2$ V617F are positive when assessed using appropriately sensitive allele-specific assays, a small proportion of patients with PV are negative for the JAK2 V617F allele $^{[10,19,20,52]}$. In order to search for alternate alleles that might result in the activation of Jak-Stat signaling, Scott et al. analyzed patients with $J A K 2 V 617 F$-negative PV for somatic mutations in all exons of $J A K 1$, $J A K 2$, JAK3, TYK2, STAT5A and STAT5B ${ }^{[53]}$. Genomic analysis identified four novel somatic mutations in exon 12 of $J A K 2$; one novel allele was a point mutation that results in the substitution of lysine for leucine at codon 539 (K539L), and three additional alleles were small deletions or insertions involving codons 538 to 543. In vitro colony assays showed that $J A K 2$ exon 12 mutations were present in all EPOindependent colonies have grown from these patients. Expression of these novel JAK2 mutant kinases in $\mathrm{Ba} / \mathrm{F} 3$ cells co-expressing EPOR, resulted in transformation to factor-independent growth, and in activation 
of downstream signaling pathways in an analogous fashion to the canonical $J A K 2 V 617 F$ allele. In addition, expression of the $J A K 2$ exon 12 mutations in a murine BMT assay recapitulated the phenotype of JAK2 V617F, with recipient mice developing; polycythemia, splenomegaly, and erythroid expansion. Unlike JAK2 V617F, JAK2 exon 12 mutations are only observed in $J A K 2 V 617 F$-negative PV, and are specific to patients who present with isolated erythrocytosis without concomitant leukocytosis or thrombocytosis. These data indicate that $J A K 2$ exon 12 mutations contribute to the pathogenesis of $J A K 2 \mathrm{~V} 617 \mathrm{~F}$ negative PV, plus different activating JAK2 alleles are associated with different clinical phenotypes.

\section{Additional Inherited and Acquired Alleles in MPD}

Although, existing data indicates that acquisition of $J A K 2 \mathrm{~V} 617 \mathrm{~F}$ mutations contributes to the pathogenesis of PV, ET and PMF, there are probably additional genetic events that contribute to the development of these MPD. Given that the identical point mutation occurs in three related, but clinically distinct disorders, additional genetic factors must cooperate with the $J A K 2 \mathrm{~V} 617 \mathrm{~F}$ kinase to determine the phenotype of $J A K 2$ V617F-positive MPD. Genetic data from families with a predisposition to develop MPD support this hypothesis. Several groups have identified families with more than one member with a diagnosis of $\mathrm{PV}$, ET or $\mathrm{PMF}^{[60,61]}$. Gain-of-function mutations in $\mathrm{KRAS}^{[62]}$ and $\mathrm{RET}^{[63]}$ have been identified in familial cancer predisposition syndromes; however, analysis of $J A K 2 V 617 F$ mutational status in familial MPD has not identified the germline $J A K 2 V 617 F$ mutations ${ }^{[64,65]}$. By contrast, somatic JAK2 V617F mutations are identified in some, but not all, affected members in these kindreds. These data are consistent with the notion that there are heritable alleles that predispose to the acquisition of JAK2 V617F mutations and to the development of PV, ET and PMF. Although, the identity of these predisposition alleles is not known, it is attractive to hypothesize that these MPD predisposition alleles modulate JAK2 signaling and increase the selective advantage of cells that acquire the $J A K 2$ V617F allele.

In addition, several lines of evidence suggest there might be a 'pre-JAK2 V617F' transformed hematopoietic progenitor. Patients with $\mathrm{PV}, \mathrm{ET}$ or PMF are at an increased risk for the development of AML, and although $J A K 2 \mathrm{~V} 617 \mathrm{~F}$ mutations are relatively uncommon in de novo 
AML they are present in many patients with AML secondary to a $\mathrm{MPD}^{[18]}$. However, two recent studies have demonstrated that a significant proportion of patients with a history of $J A K 2 \mathrm{~V} 617 \mathrm{~F}$-positive MPD develop a JAK2 V617F-negative AML ${ }^{[51,66]}$. Cytogenetic and clonality analyses in a small number of cases suggest; the $J A K 2 \mathrm{~V} 617 \mathrm{~F}$ positive MPD and $J A K 2 V 617 F$-negative AML arise from the same clone $^{[66]}$. Cytogenetic abnormalities occur in a subset of patients with PV, ET or PMF, including deletions on the long arm of chromosome $20^{[67]}$. In a small number of MPD patients, cytogenetic analyses show that all hematopoietic cells possess $20 \mathrm{q}$ deletions, but only a subset of these cells carry the $J A K 2 \quad V 617 F$ allele ${ }^{[68,69]}$. These data indicate additional mutations can precede the acquisition of JAK2 V617F mutations; whether these mutations are distinct from the alleles that contribute to familial MPD is not known. Given that JAK2 V617Fnegative MPD patients do not become $J A K 2 V 617 F$ positive during the course of their disease It is likely that the pre-JAK2 clone does not manifest as a clinically apparent MPD, and the mutations that precede the acquisition of $J A K 2 \mathrm{~V} 617 \mathrm{~F}$ are distinct from those that activate signaling in the absence of $J A K 2 V 617 F$. Given that murine BMT experiments suggest that $J A K 2 \quad V 617 F$ is sufficient to induce a PV phenotype, cooperating alleles might not be present in all patients with $J A K 2 \mathrm{V6} 6 \mathrm{~F}$ positive MPD.

\section{Future Directions}

Although, our understanding of the pathogenesis of PV, ET and PMF has greatly improved by the discovery of the $J A K 2 V 617 F$ allele, future studies will allow us to better understand the molecular pathogenesis of these MPD; to create more accurate genetic models of MPD and to develop molecularly targeted therapies for patients with these disorders. Current and future research into the genetic basis of MPD will include screens of JAK signaling molecules to identify mutant alleles in JAK2- and MPL-negative MPD, as well as genome-wide studies to identify inherited and/or acquired events that cooperate with $J A K 2 \mathrm{~V} 617 \mathrm{~F}$. Moreover, detailed investigation of signal-transduction cascades activated by JAK2 V617F will delineate the role and requirement for different signaling pathways in hematopoietic transformation. Most importantly, the development of specific, potent inhibitors of JAK2 will allow assessing whether targeted therapy against 
JAK2 results in significant clinical efficacy. Given that JAK pathway activation is commonly observed in many different human malignancies $^{[24]}$, it would predict that genomic screens will identify additional mutations that activate this signaling pathway in hematopoietic and epithelial tumors, The pharmacological inhibition of JAK kinase signaling will be of value in the treatment of human malignancies.

\section{References}

[1] Dameshek W. Some speculations on the myeloproliferative syndromes. Blood 1951; 6(4): 372-375.

[2] Bartram CR, de Klein A, Hagemeijer A, van Agthoven T, Geurts van Kessel A, Bootsma D, Grosveld G, Ferguson-Smith MA, Davies T, Stone M, et al. Translocation of c-ab1 oncogene correlates with the presence of a Philadelphia chromosome in chronic myelocytic leukaemia. Nature 1983; 306(5940): 277-280.

[3] Golub TR, Barker GF, Lovett M, Gilliland DG. Fusion of PDGF receptor beta to a novel ets-like gene, tel, in chronic myelomonocytic leukemia with $t(5 ; 12)$ chromosomal translocation. Cell 1994; 77(2): 307-316.

[4] Cools J, DeAngelo DJ, Gotlib J, Stover EH, Legare RD, Cortes J, Kutok J, Clark J, Galinsky I, Griffin JD, Cross NC, Tefferi A, Malone J, Alam R, Schrier SL, Schmid J, Rose M, Vandenberghe P, Verhoef G, Boogaerts M, Wlodarska I, Kantarjian H, Marynen P, Coutre SE, Stone R, Gilliland DG. A tyrosine kinase created by fusion of the PDGFRA and FIP1L1 genes as a therapeutic target of imatinib in idiopathic hypereosinophilic syndrome. N Engl J Med 2003; 348(13): 1201-1214.

[5] Longley BJ, Tyrrell L, Lu SZ, Ma YS, Langley K, Ding TG, Duffy T, Jacobs P, Tang LH, Modlin I. Somatic c-KIT activating mutation in urticaria pigmentosa and aggressive mastocytosis: establishment of clonality in a human mast cell neoplasm. Nat Genet 1996; 12(3): 312-314.

[6] Druker BJ, Talpaz M, Resta DJ, Peng B, Buchdunger E, Ford JM, Lydon NB, Kantarjian H, Capdeville R, Ohno-Jones S, Sawyers CL. Efficacy and safety of a specific inhibitor of the BCR-ABL tyrosine kinase in chronic myeloid leukemia. $N$ Engl $J$ Med 2001; 344(14): 1031-1037.

[7] Apperley JF, Gardembas M, Melo JV, Russell-Jones R, Bain BJ, Baxter EJ, Chase A, Chessells JM, Colombat M, Dearden CE, Dimitrijevic S, Mahon FX, Marin D, Nikolova Z, Olavarria E, Silberman S, Schultheis B, Cross NC, Goldman JM. Response to imatinib mesylate in patients with chronic myeloproliferative diseases with rearrangements of the platelet-derived growth factor receptor beta. $N$ Engl J Med 2002; 347(7): 481-487.

[8] Levine RL, Wadleigh M, Cools J, Ebert BL, Wernig G, Huntly BJ, Boggon TJ, Wlodarska I, Clark JJ, Moore S, Adelsperger J, Koo S, Lee JC, Gabriel S, Mercher T, D'Andrea A, Fröhling S, Döhner K, Marynen P, Vandenberghe P, Mesa RA, Tefferi A, Griffin JD, Eck MJ, Sellers WR, Meyerson M, Golub TR, Lee SJ, Gilliland DG. Activating mutation in the tyrosine kinase JAK2 in polycythemia vera, essential thrombocythemia, and myeloid metaplasia with myelofibrosis. Cancer Cell 2005; 7(4): 387-397.

[9] James C, Ugo V, Le Couédic JP, Staerk J, Delhommeau F, Lacout C, Garçon L, Raslova H, Berger R, Bennaceur-Griscelli A, Villeval JL, Constantinescu SN, Casadevall N, Vainchenker W. A unique clonal JAK2 mutation leading to constitutive signalling causes polycythaemia vera. Nature 2005; 434(7037): 1144-1148. 
[10] Baxter EJ, Scott LM, Campbell PJ, East C, Fourouclas N, Swanton S, Vassiliou GS, Bench AJ, Boyd EM, Curtin N, Scott MA, Erber WN, Green AR. Cancer Genome Project. Acquired mutation of the tyrosine kinase JAK2 in human myeloproliferative disorders. Lancet 2005; 365(9464): 1054-1061.

[11] Kralovics R, Passamonti F, Buser AS, Teo SS, Tiedt R, Passweg JR, Tichelli A, Cazzola M, Skoda RC. A gain-of-function mutation of JAK2 in myeloproliferative disorders. N Engl J Med 2005; 352(17): 1779-1790.

[12] Delhommeau F, Dupont S, Tonetti C, Massé A, Godin I, Le Couedic JP, Debili N, Saulnier P, Casadevall N, Vainchenker W, Giraudier S. Evidence that the JAK2 G1849T (V617F) mutation occurs in a lymphomyeloid progenitor in polycythemia vera and idiopathic myelofibrosis. Blood 2007; 109(1): 71-77.

[13] Ishii T, Bruno E, Hoffman R, Xu M. Involvement of various hematopoietic-cell lineages by the JAK2V617F mutation in polycythemia vera. Blood 2006; 108(9): 3128-3134.

[14] Jamieson CH, Gotlib J, Durocher JA, Chao MP, Mariappan MR, Lay M, Jones C, Zehnder JL, Lilleberg SL, Weissman IL. The JAK2 V617F mutation occurs in hematopoietic stem cells in polycythemia vera and predisposes toward erythroid differentiation. Proc Natl Acad Sci U S A 2006; 103(16): 6224-629.

[15] Huntly BJ, Shigematsu H, Deguchi K, Lee BH, Mizuno S, Duclos N, Rowan R, Amaral S, Curley D, Williams IR, Akashi K, Gilliland DG. MOZ-TIF2, but not BCR-ABL, confers properties of leukemic stem cells to committed murine hematopoietic progenitors. Cancer Cell 2004; 6(6): 587-596.

[16] Kralovics R, Guan Y, Prchal JT. Acquired uniparental disomy of chromosome 9p is a frequent stem cell defect in polycythemia vera. Exp Hematol 2002; 30(3): 229-236.

[17] Scott LM, Scott MA, Campbell PJ, Green AR. Progenitors homozygous for the V617F mutation occur in most patients with polycythemia vera, but not essential thrombocythemia. Blood 2006; 108(7): 2435-2437.

[18] Levine RL, Loriaux M, Huntly BJ, Loh ML, Beran M, Stoffregen E, Berger R, Clark JJ, Willis SG, Nguyen KT, Flores NJ, Estey E, Gattermann N, Armstrong S, Look AT, Griffin JD, Bernard OA, Heinrich MC, Gilliland DG, Druker B, Deininger MW. The JAK2V617F activating mutation occurs in chronic myelomonocytic leukemia and acute myeloid leukemia, but not in acute lymphoblastic leukemia or chronic lymphocytic leukemia. Blood 2005; 106(10): 3377-3379.

[19] Jelinek J, Oki Y, Gharibyan V, Bueso-Ramos C, Prchal JT, Verstovsek S, Beran M, Estey E, Kantarjian HM, Issa JP. JAK2 mutation $1849 \mathrm{G}>\mathrm{T}$ is rare in acute leukemias but can be found in CMML, Philadelphia chromosome-negative CML, and megakaryocytic leukemia. Blood 2005; 106(10): 3370-3373.

[20] Levine RL, Belisle C, Wadleigh M, Zahrieh D, Lee S, Chagnon P, Gilliland DG, Busque L. X-inactivation-based clonality analysis and quantitative JAK2V617F assessment reveal a strong association between clonality and JAK2V617F in PV but not ET/MMM, and identifies a subset of JAK2V617F-negative ET and MMM patients with clonal hematopoiesis. Blood 2006; 107(10): 4139-4141.

[21] Steensa DP, Dewald GW, Lasho TL, Powell HL, McClure RF, Levine RL, Gilliland DG, Tefferi A. The JAK2 V617F activating tyrosine kinase mutation is an infrequent event in both "atypical" myeloproliferative disorders and myelodysplastic syndromes. Blood 2005; 106(4): 1207-1209.

[22] Scott LM, Campbell PJ, Baxter EJ, Todd T, Stephens P, Edkins S, Wooster R, Stratton MR, Futreal PA, Green AR. The V617F JAK2 mutation is uncommon in cancers and in myeloid malignancies other than the classic myeloproliferative disorders. Blood 2005; 106(8): 2920-2921.

[23] Verma A, Kambhampati S, Parmar S, Platanias LC. Jak family of kinases in cancer. Cancer Metastasis Rev 2003; 22(4): 423-434. 
[24] Walters DK, Mercher T, Gu TL, O'Hare T, Tyner JW, Loriaux M, Goss VL, Lee KA, Eide CA, Wong MJ, Stoffregen EP, McGreevey L, Nardone J, Moore SA, Crispino J, Boggon TJ, Heinrich MC, Deininger MW, Polakiewicz RD, Gilliland DG, Druker BJ. Activating alleles of JAK3 in acute megakaryoblastic leukemia. Cancer Cell 2006; 10(1): $65-75$.

[25] Joos S, Küpper M, Ohl S, von Bonin F, Mechtersheimer G, Bentz M, Marynen P, Möller P, Pfreundschuh M, Trümper L, Lichter P. Genomic imbalances including amplification of the tyrosine kinase gene JAK2 in CD30+ Hodgkin cells. Cancer Res 2000; 60(3): 549-552.

[26] Melzner I, Bucur AJ, Brüderlein S, Dorsch K, Hasel C, Barth TF, Leithäuser F, Möller P. Biallelic mutation of SOCS-1 impairs JAK2 degradation and sustains phosphoJAK2 action in the MedB-1 mediastinal lymphoma line. Blood 2005; 105(6): 2535-2542.

[27] Weniger MA, Melzner I, Menz CK, Wegener S, Bucur AJ, Dorsch K, Mattfeldt T, Barth TF, Möller P. Mutations of the tumor suppressor gene SOCS-1 in classical Hodgkin lymphoma are frequent and associated with nuclear phospho-STAT5 accumulation. Oncogene 2006; 25(18): 2679-2684.

[28] Melzner I, Weniger MA, Bucur AJ, Brüderlein S, Dorsch K, Hasel C, Leithäuser F, Ritz O, Dyer MJ, Barth TF, Möller P. Biallelic deletion within 16p13.13 including SOCS-1 in Karpas1106P mediastinal B-cell lymphoma line is associated with delayed degradation of JAK2 protein. Int J Cancer 2006; 118(8): 1941-1944.

[29] Galm O, Yoshikawa H, Esteller M, Osieka R, Herman JG. SOCS-1, a negative regulator of cytokine signaling, is frequently silenced by methylation in multiple myeloma. Blood 2003; 101(7): 2784-2788.

[30] Parganas E, Wang D, Stravopodis D, Topham DJ, Marine JC, Teglund S, Vanin EF, Bodner S, Colamonici OR, van Deursen JM, Grosveld G, Ihle JN. Jak2 is essential for signaling through a variety of cytokine receptors. Cell 1998; 93(3): 385-395.

[31] Saharinen P, Takaluoma K, Silvennoinen O. Regulation of the Jak2 tyrosine kinase by its pseudokinase domain. Mol Cell Biol 2000; 20(10): 3387-3395.

[32] Lindauer K, Loerting T, Liedl KR, Kroemer RT. Prediction of the structure of human Janus kinase 2 (JAK2) comprising the two carboxy-terminal domains reveals a mechanism for autoregulation. Protein Eng 2001; 14(1): 27-37.

[33] Ihle JN, Gilliland DG. Jak2: normal function and role in hematopoietic disorders. Curr Opin Genet Dev 2007; 17(1): 8-14.

[34] Zhao R, Xing S, Li Z, Fu X, Li Q, Krantz SB, Zhao ZJ. Identification of an acquired JAK2 mutation in polycythemia vera. $J$ Biol Chem 2005; 280(24): 22788-22792.

[35] Prchal JF, Axelrad AA. Letter: Bone-marrow responses in polycythemia vera. $N$ Engl $J$ Med 1974; 290(24): 1382.

[36] Lu X, Levine R, Tong W, Wernig G, Pikman Y, Zarnegar S, Gilliland DG, Lodish H. Expression of a homodimeric type I cytokine receptor is required for JAK2V617F-mediated transformation. Proc Natl Acad Sci U S A 2005; 102(52): 18962-18967.

[37] Garçon L, Rivat C, James C, Lacout C, Camara-Clayette V, Ugo V, Lecluse Y, Bennaceur-Griscelli A, Vainchenker W. Constitutive activation of STAT5 and Bcl-xL overexpression can induce endogenous erythroid colony formation in human primary cells. Blood 2006; 108(5): 1551-1554.

[38] Röder S, Steimle C, Meinhardt G, Pahl HL. STAT3 is constitutively active in some patients with Polycythemia rubra vera. Exp Hematol 2001; 29(6): 694-702.

[39] Silva M, Richard C, Benito A, Sanz C, Olalla I, Fernández-Luna JL. Expression of Bcl-x in erythroid precursors from patients with polycythemia vera. N Engl J Med 1998; 338(9): 564-571.

[40] Schwaller J, Parganas E, Wang D, Cain D, Aster JC, Williams IR, Lee CK, Gerthner R, Kitamura T, Frantsve J, Anastasiadou E, Loh ML, Levy DE, Ihle JN, Gilliland DG. 
Stat5 is essential for the myelo- and lymphoproliferative disease induced by TEL/JAK2. Mol Cell 2000; 6(3): 693-704.

[41] Nicholson SE, Willson TA, Farley A, Starr R, Zhang JG, Baca M, Alexander WS, Metcalf D, Hilton DJ, Nicola NA. Mutational analyses of the SOCS proteins suggest a dual domain requirement but distinct mechanisms for inhibition of LIF and IL-6 signal transduction. EMBO J 1999; 18(2): 375-385.

[42] Sasaki A, Yasukawa H, Shouda T, Kitamura T, Dikic I, Yoshimura A. CIS3/SOCS-3 suppresses erythropoietin (EPO) signaling by binding the EPO receptor and JAK2. J Biol Chem 2000; 275(38): 29338-29347.

[43] Frantsve J, Schwaller J, Sternberg DW, Kutok J, Gilliland DG. Socs-1 inhibits TELJAK2-mediated transformation of hematopoietic cells through inhibition of JAK2 kinase activity and induction of proteasome-mediated degradation. Mol Cell Biol 2001; 21(10): 3547-3557.

[44] Hookham MB, Elliott J, Suessmuth Y, Staerk J, Ward AC, Vainchenker W, Percy MJ, McMullin MF, Constantinescu SN, Johnston JA. The myeloproliferative disorderassociated JAK2 V617F mutant escapes negative regulation by suppressor of cytokine signaling 3. Blood 2007; 109(11): 4924-4929.

[45] Wernig G, Mercher T, Okabe R, Levine RL, Lee BH, Gilliland DG. Expression of Jak2V617F causes a polycythemia vera-like disease with associated myelofibrosis in a murine bone marrow transplant model. Blood 2006; 107(11): 4274-4281.

[46] Lacout C, Pisani DF, Tulliez M, Gachelin FM, Vainchenker W, Villeval JL. JAK2V617F expression in murine hematopoietic cells leads to MPD mimicking human PV with secondary myelofibrosis. Blood 2006; 108(5): 1652-1660.

[47] Zaleskas VM, Krause DS, Lazarides K, Patel N, Hu Y, Li S, Van Etten RA. Molecular pathogenesis and therapy of polycythemia induced in mice by JAK2 V617F. PLoS ONE 2006; 1(e18): 1-11.

[48] Bumm TG, Elsea C, Corbin AS, Loriaux M, Sherbenou D, Wood L, Deininger J, Silver RT, Druker BJ, Deininger MW. Characterization of murine JAK2V617F-positive myeloproliferative disease. Cancer Res 2006; 66(23): 11156-11165.

[49] Daley GQ, Van Etten RA, Baltimore D. Induction of chronic myelogenous leukemia in mice by the P210bcr/abl gene of the Philadelphia chromosome. Science 1990; 247(4944): 824-300.

[50] Cools J, Stover EH, Boulton CL, Gotlib J, Legare RD, Amaral SM, Curley DP, Duclos N, Rowan R, Kutok JL, Lee BH, Williams IR, Coutre SE, Stone RM, DeAngelo DJ, Marynen P, Manley PW, Meyer T, Fabbro D, Neuberg D, Weisberg E, Griffin JD, Gilliland DG. PKC412 overcomes resistance to imatinib in a murine model of FIP1L1PDGFRalpha-induced myeloproliferative disease. Cancer Cell 2003; 3(5): 459-469.

[51] Campbell PJ, Baxter EJ, Beer PA, Scott LM, Bench AJ, Huntly BJ, Erber WN, Kusec R, Larsen TS, Giraudier S, Le Bousse-Kerdilès MC, Griesshammer M, Reilly JT, Cheung BY, Harrison CN, Green AR. Mutation of JAK2 in the myeloproliferative disorders: timing, clonality studies, cytogenetic associations, and role in leukemic transformation. Blood 2006; 108(10): 3548-3555.

[52] Jones AV, Kreil S, Zoi K, Waghorn K, Curtis C, Zhang L, Score J, Seear R, Chase AJ, Grand FH, White H, Zoi C, Loukopoulos D, Terpos E, Vervessou EC, Schultheis B, Emig M, Ernst T, Lengfelder E, Hehlmann R, Hochhaus A, Oscier D, Silver RT, Reiter A, Cross NC. Widespread occurrence of the JAK2 V617F mutation in chronic myeloproliferative disorders. Blood 2005; 106(6): 2162-2168.

[53] Scott LM, Tong W, Levine RL, Scott MA, Beer PA, Stratton MR, Futreal PA, Erber WN, McMullin MF, Harrison CN, Warren AJ, Gilliland DG, Lodish HF, Green AR. JAK2 exon 12 mutations in polycythemia vera and idiopathic erythrocytosis. $N$ Engl J Med 2007; 356(5): 459-468. 
[54] Arcasoy MO, Degar BA, Harris KW, Forget BG. Familial erythrocytosis associated with a short deletion in the erythropoietin receptor gene. Blood 1997; 89(12): 4628-4635.

[55] Pikman Y, Lee BH, Mercher T, McDowell E, Ebert BL, Gozo M, Cuker A, Wernig G, Moore S, Galinsky I, DeAngelo DJ, Clark JJ, Lee SJ, Golub TR, Wadleigh M, Gilliland DG, Levine RL. MPLW515L is a novel somatic activating mutation in myelofibrosis with myeloid metaplasia. PLoS Med 2006; 3(7): e270 1140-1151.

[56] Ding J, Komatsu H, Wakita A, Kato-Uranishi M, Ito M, Satoh A, Tsuboi K, Nitta M, Miyazaki H, Iida S, Ueda R. Familial essential thrombocythemia associated with a dominant-positive activating mutation of the c-MPL gene, which encodes for the receptor for thrombopoietin. Blood 2004; 103(11): 4198-4200.

[57] Pardanani AD, Levine RL, Lasho T, Pikman Y, Mesa RA, Wadleigh M, Steensma DP, Elliott MA, Wolanskyj AP, Hogan WJ, McClure RF, Litzow MR, Gilliland DG, Tefferi A. MPL515 mutations in myeloproliferative and other myeloid disorders: a study of 1182 patients. Blood 2006; 108(10): 3472-3476.

[58] Roberts AE, Araki T, Swanson KD, Montgomery KT, Schiripo TA, Joshi VA, Li L, Yassin Y, Tamburino AM, Neel BG, Kucherlapati RS. Germline gain-of-function mutations in SOS1 cause Noonan syndrome. Nat Genet 2007; 39(1): 70-74.

[59] Tartaglia M, Pennacchio LA, Zhao C, Yadav KK, Fodale V, Sarkozy A, Pandit B, Oishi K, Martinelli S, Schackwitz W, Ustaszewska A, Martin J, Bristow J, Carta C, Lepri F, Neri C, Vasta I, Gibson K, Curry CJ, Siguero JP, Digilio MC, Zampino G, Dallapiccola B, Bar-Sagi D, Gelb BD. Gain-of-function SOS1 mutations cause a distinctive form of Noonan syndrome. Nat Genet 2007; 39(1): 75-79.

[60] Gilbert HS. Familial myeloproliferative disease. Baillieres Clin Haematol 1998; 11(4): 849-858.

[61] Skoda R, and Prchal JT. Lessons from familial myeloproliferative disorders. Semin Hematol 2005; 42(4): 266-273.

[62] Schubbert S, Zenker M, Rowe SL, Böll S, Klein C, Bollag G, van der Burgt I, Musante L, Kalscheuer V, Wehner LE, Nguyen H, West B, Zhang KY, Sistermans E, Rauch A, Niemeyer CM, Shannon K, Kratz CP. Germline KRAS mutations cause Noonan syndrome. Nat Genet 2006; 38(3): 331-336.

[63] Mulligan LM, Kwok JB, Healey CS, Elsdon MJ, Eng C, Gardner E, Love DR, Mole SE, Moore JK, Papi L, et al. Germ-line mutations of the RET proto-oncogene in multiple endocrine neoplasia type 2A. Nature 1993; 363(6428): 458-460.

[64] Cario H, Goerttler PS, Steimle C, Levine RL, Pahl HL. The JAK2V617F mutation is acquired secondary to the predisposing alteration in familial polycythaemia vera. $\mathrm{Br} \mathrm{J}$ Haematol 2005; 130(5): 800-801.

[65] Bellanné-Chantelot C, Chaumarel I, Labopin M, Bellanger F, Barbu V, De Toma C, Delhommeau F, Casadevall N, Vainchenker W, Thomas G, Najman A. Genetic and clinical implications of the Val617Phe JAK2 mutation in 72 families with myeloproliferative disorders. Blood 2006; 108(1): 346-352.

[66] Theocharides A, Boissinot M, Girodon F, Garand R, Teo SS, Lippert E, Talmant P, Tichelli A, Hermouet S, Skoda RC. Leukemic blasts in transformed JAK2-V617Fpositive myeloproliferative disorders are frequently negative for the JAK2-V617F mutation. Blood 2007; 110(1): 375-379.

[67] Asimakopoulos FA, White NJ, Nacheva E, Green AR. Molecular analysis of chromosome $20 \mathrm{q}$ deletions associated with myeloproliferative disorders and myelodysplastic syndromes. Blood 1994; 84(9): 3086-3094.

[68] Kralovics R, Teo SS, Li S, Theocharides A, Buser AS, Tichelli A, Skoda RC. Acquisition of the V617F mutation of JAK2 is a late genetic event in a subset of patients with myeloproliferative disorders. Blood 2006; 108(4): 1377-1380.

[69] Tefferi A. JAK2 mutations and clinical practice in myeloproliferative neoplasms. Cancer J 2007; 13(6): 366-371. 


\section{دور التايروسين كاينيز في تطور سرطان الدم المزمن}

\section{ممدوح عبد الله قارى}

قسم تقنية المختبرات الطبية ، كلية العلوم الطبية التطبيقية ،

مركز التمبز لبحوث الجينوم الطبي ، جامعة الملك عبد العزيز

جدة - المدلكة العربية السعودية

الستخلص. ابيضاض الدم (اللوكيميا) يعرف بأنه خلايا الدم البيضاء

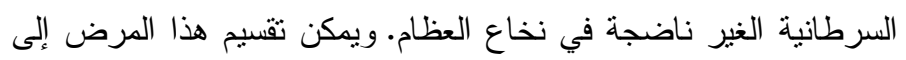

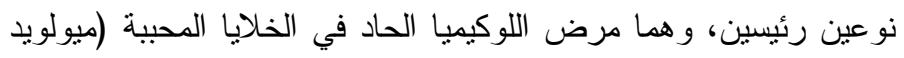

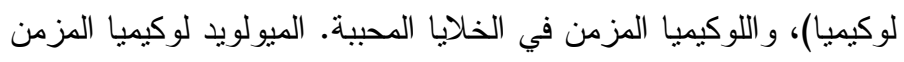

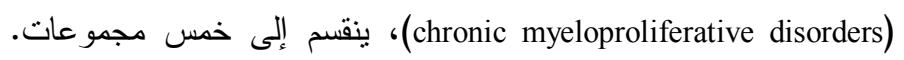

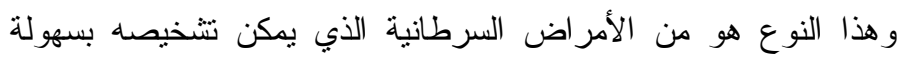

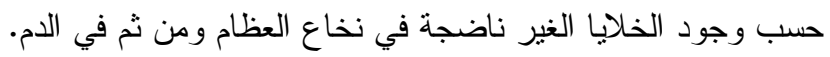

توجد بعض البحوث التي تؤكد أن الطفرات الجينية - التي تحدث

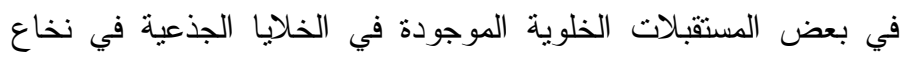

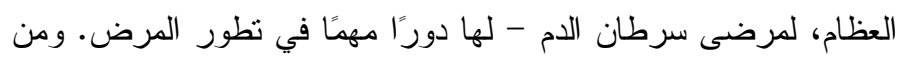

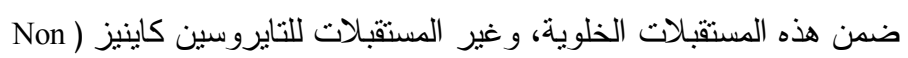
Jak2 (receptor tyrosine kinases and Receptor Tyrosine kinases non Receptor Tyrosine ) عبارة عن غير مستقبل للتايروسين كاينيز

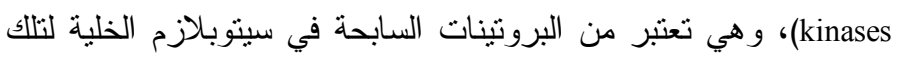

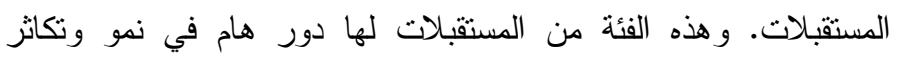

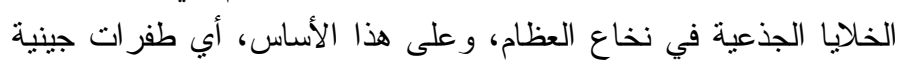

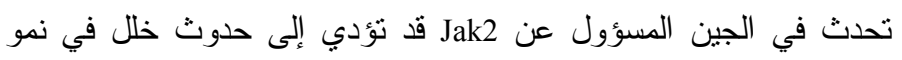

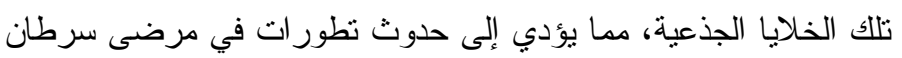

